\title{
Characteristics of acute congestive heart failure with normal ejection fraction and less elevated B-type natriuretic peptide Ken Shimamoto $^{\dagger 1}$, Natsuha Koike ${ }^{\dagger 2}$, Kiyoko Mizuochi ${ }^{\dagger 2}$, Miho Honma ${ }^{\dagger 2}$, Yufuko Kasai ${ }^{\dagger 2}$, Akiko Sakai ${ }^{\dagger 2}$, Etsuko Fujita ${ }^{\dagger 2}$ and Masatoshi Kawana*1
}

\begin{abstract}
Address: ${ }^{1}$ Department of Cardiology, Tokyo Women's Medical University Aoyama Hospital, Tokyo, Japan and ${ }^{2}$ Department of Cardiology, Tokyo Women's Medical University Institute of Geriatrics, Tokyo, Japan

Email: Ken Shimamoto - kshimamo@ah.twmu.ac.jp; Natsuha Koike - natsuha0504@sunny.ocn.ne.jp;

Kiyoko Mizuochi - kiyochiru@yahoo.co.jp; Miho Honma - miho-h@ah.twmu.ac.jp; Yufuko Kasai - yufuko.k@ah.twmu.ac.jp; Akiko Sakai - akiko.s@ah.twmu.ac.jp; Etsuko Fujita - e-shiono@ah.twmu.ac.jp; Masatoshi Kawana* - mkawana@hij.twmu.ac.jp

* Corresponding author †Equal contributors
\end{abstract}

Published: 24 January 2009

BMC Cardiovascular Disorders 2009, 9:2 doi:10.1/86/147|-226I-9-2

This article is available from: http://www.biomedcentral.com//47I-226I/9/2

(c) 2009 Shimamoto et al; licensee BioMed Central Ltd.

This is an Open Access article distributed under the terms of the Creative Commons Attribution License (http://creativecommons.org/licenses/by/2.0), which permits unrestricted use, distribution, and reproduction in any medium, provided the original work is properly cited.
Received: 6 August 2008

Accepted: 24 January 2009

\begin{abstract}
Background: Heterogeneity in B-type natriuretic peptide (BNP) levels, especially among individuals with acute heart failure with normal left ventricular ejection fraction (HFNEF), can cause confusion in interpreting results. We investigated the characteristics of cases of acute HFNEF with only modestly elevated BNP.
\end{abstract}

Methods: One hundred forty-two patients with acute or acute exacerbation of chronic HFNEF were divided into two groups by BNP level: BNP $<100 \mathrm{pg} / \mathrm{ml}(\mathrm{NB}$ group, $\mathrm{n}=45)$ and $\mathrm{BNP} \geq 100$ $\mathrm{pg} / \mathrm{ml}$ ( $B$ group, $\mathrm{n}=97$ ). We compared clinical findings, echocardiography results, and neurohormonal factors between these two groups.

Results: In the NB group, a history of open-heart surgery (OHS) was more frequent $(71 \%$ vs. $22 \%$, $p<0.000 \mathrm{I})$ and hypertension was less frequent $(p=0.0005)$. Left atrial diameter (LAd) was higher $(p=0.0026)$, while interventricular septal thickness, posterior wall thickness, relative wall thickness, left ventricular mass index were lower $(p=0.0005, p=0.0225, p=0.0114, p=0.005 \mathrm{I}$, respectively) in the NB group. In patients with HFNEF, a history of OHS remained an independent predictor of BNP level $(<100 \mathrm{pg} / \mathrm{ml}$ ) after adjustment for hypertension, age, LAd, and interventricular septal thickness (odds ratio 3.6, $\mathrm{p}=0.0252$ ).

Conclusion: We found associations between acute HFNEF with less elevated BNP and a history of OHS. In a patient suspected of HFNEF, a history of OHS is considered diagnostic evidence of presence of diastolic heart failure when plasma levels of BNP are less elevated.

\section{Background}

Heart failure with normal left ventricular ejection fraction (HFNEF), also called heart failure with normal systolic function or diastolic heart failure, accounts for $40-50 \%$ of cases of heart failure. This condition is commonly observed in elderly women, particularly those with a history of hypertension, left ventricular hypertrophy, or diabetes mellitus. Congestive symptoms, although generally milder, do not differ from those in systolic heart failure (SHF), in which ejection fraction is reduced. Although 
HFNEF is generally associated with a more favorable prognosis than SHF, the mortality rate for HFNEF and SHF are nearly equivalent in the elderly. Diagnosis of HFNEF must be made quickly to enable appropriate treatment, but this is often difficult, particularly in elderly patients who have comorbidities such as chronic lung or heart disease. Btype natriuretic peptide (BNP) level is a useful marker not only in the diagnosis and determination of the severity of heart failure, but also in the assessment of treatment effects [1-4]. However, there is marked heterogeneity in BNP levels among subjects with heart failure. Although a BNP level of approximately $100 \mathrm{pg} / \mathrm{mL}$ is regarded as a criterion for the diagnosis of heart failure, the interpretation of BNP level with regard to HFNEF is unclear [5-8]. BNP level has recently been reported to be also elevated in conditions other than heart disease, such as sepsis and subarachnoid hemorrhage, and to be affected by factors such as tachycardia, thyroid hormone, glucocorticoid, endothelin, angiotensin II, and renal function [9]. Understanding of extracardiac factors affecting BNP level is crucial when BNP level is used for differentiating heart disease. On the other hand, BNP level does not increase in heart failure resulting from tamponade or constrictive pericarditis $[10,11]$. In addition, because BNP level generally tends to be lower in HFNEF compared to SHF $[12,13]$, the effects of extramyocardial factors must be considered in the development of HFNEF. In this study, we investigated the characteristics of cases of HFNEF with only modestly elevated BNP during the acute phase.

\section{Methods}

\section{Study sample}

One hundred and forty-two cases of acute or acute exacerbation of chronic HFNEF seen in our department between 2003 and 2006 were studied. The present study was a cross-sectional observational study in which the diagnosis of heart failure was based on the Framingham Criteria [14]. In all cases, more than one cardiologist was asked to agree on the diagnosis and severity according to the Framingham Criteria and the New York Heart Association class. This investigation is in conformity with the principles outlined in the Declaration of Helsinki and was approved by the Ethical Committee of Tokyo Women's Medical University; all subjects gave their informed consent.

The determination of HFNEF was made from symptoms, signs, chest $\mathrm{x}$-ray results, and ultrasonic echocardiography (UCG) criteria (ejection fraction $\geq 50 \%$, abnormal ratio of early diastolic flow velocity to peak late atrial diastolic flow velocity, and deceleration time of peak early filling velocity) within $24 \mathrm{hr}$ of congestive heart failure event. Patients were divided into two groups with respect to BNP levels: $\mathrm{BNP}<100 \mathrm{pg} / \mathrm{ml}(\mathrm{NB}$ group, $\mathrm{n}=45)$ and $\mathrm{BNP} \geq$ $100 \mathrm{pg} / \mathrm{ml}$ (B group, $\mathrm{n}=97$ ). Patients with acute or severe mitral or aortic valvular dysfunction, myocardial infarction and obvious pulmonary disease were excluded. Cardiac abnormalities in this study included the following conditions: hypertension, diabetes mellitus, atrial fibrillation (AF), hypertrophic cardiomyopathy, and mild to moderate valvular disease. We compared clinical findings, history of open-heart surgery (OHS), hypertension, diabetes mellitus, and dyslipidemia, chest radiograph and ECG findings, parameters from echocardiography, frequency of atrial fibrillation (AF) and moderate or severe tricuspid valve regurgitation (TR), neurohormonal factors and other prognostic factors such as serum creatinine, hemoglobin and serum sodium between the two groups.

In some cases, maximal thickness of the pericardium was assessed by computed tomography (B group, $\mathrm{n}=58$, NB group, $\mathrm{n}=24$ ). Measurement were performed without zooming the pictures, using an electronic caliper that was placed where the pericardium was clearly visible and with lesser variations in thickness, namely on the anterior surface of the heart in front of the right and left ventricles.

\section{Blood sampling}

Venous blood samples were obtained after $30 \mathrm{~min}$ of supine rest on admission for radioimmunoassay measurement of B-type natriuretic peptide (BNP), A-type natriuretic peptide (ANP), plasma norepinephrine, and plasma aldosterone concentration (PAC) levels. BNP level was measured by standard radioimmunoassay (Shionoria BNP kit; Shionogi Co., Osaka, Japan) within 24 hours. Values of BNP $<43 \mathrm{pg} / \mathrm{ml}$ were considered normal.

\section{Echocardiography}

All subjects underwent standard two-dimensional echocardiography with a commercially available system (Sonos 5500, Philips Medical Systems, Best, The Netherlands and Vivid 7, GE Medical System, Horton, Norway) using a multi-frequency $\mathrm{MHz}$ transducer. Cardiac function was evaluated by M-mode echocardiography guided by two-dimensional imaging; left atrial diameters (LAd), interventricular septal thickness (IVST), posterior wall thickness (PWT), left ventricular end-diastolic diameters (LVDd), end-systolic diameters (LVDs), and ejection fraction (EF) were measured. The ratio of peak early diastolic flow velocity to peak late atrial diastolic flow velocity (E/ A), deceleration time of peak early filling velocity (Dct), and right ventricular systolic pressure (RVSP) were measured by Doppler imaging. Left ventricular mass index (LVMI) was measured using the method of Simone et al. [14], while relative wall thickness (RWT) was measured using the method of Daniels et al. [15,16].

In addition, as a sub-analysis, patients with a history of OHS were subdivided into B and NB group for compari- 
son of UCG parameters, BNP levels, frequency of AF and TR and history of hypertension.

\section{Statistical analysis}

Continuous variables are expressed as mean \pm SD and median value. For the relationship between UCG parameters, neurohormone levels, blood pressure, heart rate, age, and other prognostic factors, Mann-Whitney's U test was performed. Differences between groups described by categorical variables were analyzed by the chi-square test for independence or Fisher's exact probability.

The independent diagnostic value of HFNEF without elevated BNP was assessed in multivariate logistic regression model for all variables that proved to be significant by univariate analysis in patients with elevated BNP and those with less elevated BNP. The following dichotomous or continuous variables were evaluated in the multivariate model: medical history of OHS and hypertension, LAd, IVST, age, and PAC. All p values less than 0.05 are regarded as having statistical significance.

\section{Results}

\section{Clinical and Neurohormonal Characteristics}

Table 1 summarizes medical therapy, clinical findings, chest radiograph and ECG findings, biochemical profiles and pericardial thickness subdivided according to the BNP levels. The subjects were 77 men and 65 women, ages $73.7 \pm 9.9$ years old (range, $33-93$ years old). The B group (age, $74.8 \pm 10.4$ years old) was significantly older $(\mathrm{p}=0.0054$ ) than the NB group (age, $71.4 \pm 8.3$ years old). Although hypertension was more common ( $\mathrm{p}=$ 0.0005 ) in the B group, no differences were observed for diabetes and dyslipidemia. According to the New York Heart Association classification, the severity of heart failure was class II in 113 patients and class III in 29 patients, with no intergroup differences. As for treatment drugs, the B group received significantly more angiotensin-converting enzyme inhibitors and angiotensin II receptor blockers, while the NB group received significantly more digitalis, diuretic drugs, and warfarin (Table 1).

The rate of exertional breathlessness was high and extrasounds were low in both groups, with no significant differences. However, the NB group had higher rates of general malaise $(\mathrm{p}=0.0018)$ and hepatomegaly $(\mathrm{p}=$ $0.0244)$. The NB group also had a higher rate of history of OHS ( $71 \%$ vs. $22 \%$; $<<0.0001)$, with a mean postoperative period of 21.1 years. The B group had a mean postoperative period of 19.7 years, demonstrating no significant differences from the NB group. In the NB group $(n=31)$, surgery involved mitral valve replacement $(M V R ; n=13)$, mitral valve plasty $(\mathrm{n}=1)$, double valve replacement (DVR) [mitral valve replacement + aortic valve replacement $(M V R+A V R)](n=9)$, open mitral commissurotomy
(OMC) $(\mathrm{n}=6)$, and coronary artery bypass graft (CABG; $n=2)$. In the B group $(n=21)$, surgery involved MVR ( $n$ $=8), \operatorname{AVR}(\mathrm{n}=3), \operatorname{DVR}(\mathrm{MVR}+\mathrm{AVR} ; \mathrm{n}=2), \operatorname{OMC}(\mathrm{n}=1)$, atrial septal defect (ASD; $n=3)$, and CABG $(n=4)$. Especially, the NB group also had a higher rate of mitral prosthesis ( $49 \%$ vs. $10 \%$; $p<0.0001)$,

No differences were observed for frequencies of high voltage, ST segment abnormality, intraventricular conduction delay, and AF on electrocardiography. Although cardiothoracic ratio on chest radiograph was greater in the NB group, no differences were observed for the frequencies of pulmonary congestion and pleural effusion. No intergroup differences were observed for mean heart rate and systolic and diastolic blood pressures on admission. The pericardial thickness in NB group tended to be thicker than that in NB group $(2.4 \pm 1.1 \mathrm{~mm}$ for B group versus $2.9 \pm 1.9 \mathrm{~mm}$ for NB group, $\mathrm{p}=0.5886$ ). No clear calcified lesions were observed on computed tomography in patients with HFNEF with less elevated BNP. The NB group had a significantly lower ANP level $(\mathrm{p}<0.0001)$ and a significantly higher PAC level $(\mathrm{p}<0.0001)$. The B group with a history of OHS had a significantly lower BNP level than that without a history of OHS $(p=0.0019)$ (Figure 1).

\section{Echocardiographic findings}

The echocardiographic parameters are shown in Table 2. No significant intergroup differences were observed for EF, LVDd, LVDs, RVSP and frequency of TR. The median values of IVST, PWT, LVMI and RWT were significantly higher in $\mathrm{B}$ group compared to NB group $(\mathrm{p}=0.0005, \mathrm{p}=$ $0.0225, \mathrm{p}=0.0051, \mathrm{p}=0.0114$, respectively), indicating greater degree of LV hypertrophy in the B group. The NB group had a larger LAd $(\mathrm{p}=0.0026)$ (Figure 2). Patients in the NB group who had a history of OHS also had marked left atrial enlargement (Figure 2). There was no significant difference in the frequency of moderate or severe TR between the two groups.

\section{Sub-analysis of the OHS group}

In the group with a history of OHS, the NB group had a larger LAd than the B group ( $p=0.0069)$ (Figure 2$)$. No significant differences were observed for left ventricular dimension, wall thickness, EF, LVMI and frequency of AF. However, the B group with had a higher frequency of hypertension than the NB group $(\mathrm{p}=0.0093)$ (data not shown).

\section{Multivariate logistic regression analysis}

Regarding logistic regression analysis, history of OHS, hypertension, IVST, LAd, age, and PAC were shown to be significant in univariate analysis, while only a history of OHS was shown to be significant in multivariate analysis (Table 3). The model showed that a history of OHS was 
Table I: Clinical and neurohormonal characteristics of the patients.

\begin{tabular}{|c|c|c|c|}
\hline & B group & NB group & $P$ \\
\hline $\mathrm{n}$ & 97 & 45 & \\
\hline Age (median) (yrs) & $74.8 \pm 10.4(77)$ & $71.4 \pm 8.3(72)$ & $0.0054^{*}$ \\
\hline Gender male $\mathrm{n}(\%)$ & $56(58)$ & $21(47)$ & 0.2186 \\
\hline Body mass index $\left(\mathrm{kg} / \mathrm{m}^{2}\right)$ & $22.1 \pm 3.7(22.2)$ & $20.8 \pm 3.6(20.7)$ & 0.0796 \\
\hline Open-heart surgery $\mathrm{n}(\%)$ & $21(22)$ & $32(7 I)$ & $<0.0001$ \\
\hline Mitral prosthesis n (\%) & $10(10)$ & $22(49)$ & $<0.0001$ \\
\hline Postoperative period (median) (yrs) & $19.7 \pm 11.0(19)$ & $21.1 \pm 9.3(21)$ & $0.6290 *$ \\
\hline Hypertension $\mathrm{n}(\%)$ & $56(58)$ & $12(27)$ & 0.0005 \\
\hline Diabetes mellitus n (\%) & $25(26)$ & $12(27)$ & 0.9103 \\
\hline Dyslipidemia $n(\%)$ & $22(23)$ & $4(8)$ & 0.0617 \\
\hline Angiotensinll receptor blockers/angiotensin- converting enzyme inhibitors n (\%) & $74(76)$ & $24(53)$ & 0.0067 \\
\hline Digitalis $\mathrm{n}(\%)$ & $21(23)$ & $23(55)$ & 0.0004 \\
\hline Calcium channel blockers $\mathrm{n}(\%)$ & $32(36)$ & $12(29)$ & 0.4245 \\
\hline$\beta$ blockers $\mathrm{n}(\%)$ & $35(39)$ & $9(21)$ & 0.0426 \\
\hline Warfarin n (\%) & $37(42)$ & $29(69)$ & 0.0030 \\
\hline Diuretics n (\%) & $55(61)$ & $37(88)$ & 0.0020 \\
\hline Spironolactone n (\%) & $34(38)$ & $26(62)$ & 0.0094 \\
\hline NYHA II n & 77 & 36 & 0.9321 \\
\hline III $n$ & 20 & 9 & \\
\hline Dyspnea n (\%) & $84(88)$ & $40(91)$ & 0.7752 \\
\hline General malaise $n(\%)$ & $9(9)$ & $14(31)$ & 0.0018 \\
\hline Extra sound $\mathrm{n}(\%)$ & $8(9)$ & $I(2)$ & 0.2711 \\
\hline LV distension n (\%) & $33(4 I)$ & $22(54)$ & 0.1948 \\
\hline Hepatomegaly n (\%) & $32(33)$ & $24(53)$ & 0.0244 \\
\hline Peripheral edema $n(\%)$ & $50(52)$ & $21(47)$ & 0.5486 \\
\hline Systolic blood pressure (median) (mmHg) & $136.2 \pm 23.6(134.0)$ & $134.4 \pm 17.2(\mid 32.0)$ & $0.6778^{*}$ \\
\hline Diastolic blood pressure (median) $(\mathrm{mmHg})$ & $74.2 \pm 14.8(72.0)$ & $72.3 \pm 13.2(70.0)$ & $0.2300^{*}$ \\
\hline Heart rate (median) (bpm) & $81.3 \pm 66.5(72.0)$ & $74.4 \pm 17.0(72.0)$ & $0.6566^{*}$ \\
\hline ANP (median) (pg/ml) & $122.5 \pm 185.4(82.0)$ & $29.0 \pm 59.6(15.0)$ & $<0.0001 *$ \\
\hline BNP (median) (pg/ml) & $380.7 \pm 259.1(318.0)$ & $59.7 \pm 27.1(60.8)$ & \\
\hline Plasma aldosterone (median) (ng/dl) & $6.9 \pm 5.7(5.0)$ & $17.6 \pm 24.1(10.8)$ & $<0.0001 *$ \\
\hline Plasma norepinephrine (median) (ng/ml) & $0.45 \pm 0.29(0.40)$ & $0.38 \pm 0.20(0.36)$ & $0.4405^{*}$ \\
\hline Serum creatinine (median) $(\mathrm{mg} / \mathrm{dl})$ & $1.07 \pm 0.46(0.94)$ & $0.96 \pm 0.48(0.90)$ & $0.2460 *$ \\
\hline Hemoglobin (median) $(\mathrm{g} / \mathrm{dl})$ & $11.9 \pm 2.1(12.1)$ & $11.8 \pm 2.1(12.3)$ & $0.9163^{*}$ \\
\hline Serum sodium (median) (mEq/L) & $140.2 \pm 3.9(|4| .0)$ & $140.1 \pm 8.6(\mid 40.0)$ & $0.1607^{*}$ \\
\hline \multicolumn{4}{|l|}{ Chest radiograph: } \\
\hline Cardiothoracic ratio (\%) & $61.2 \pm 10.0$ & $66.0 \pm 14.3$ & $0.0484^{*}$ \\
\hline Congestion n (\%) & $23(26)$ & $3(12)$ & 0.1826 \\
\hline Effusion $\mathrm{n}(\%)$ & $44(50)$ & $23(58)$ & 0.4303 \\
\hline \multicolumn{4}{|l|}{ ECG: } \\
\hline High voltage $n(\%)$ & $10(14)$ & $4(14)$ & $>0.9999$ \\
\hline ST change $\mathrm{n}(\%)$ & $34(48)$ & $13(43)$ & 0.6750 \\
\hline \multicolumn{4}{|l|}{ Intraventricular conduction disturbance } \\
\hline n (\%) & $18(21)$ & $10(28)$ & 0.4366 \\
\hline Atrial fibrillation $\mathrm{n}(\%)$ & $47(57)$ & $29(73)$ & 0.0854 \\
\hline Pericardial thickness (median) (mm) & $2.4 \pm 1.1(2.1)$ & $2.9 \pm 1.9(2.0)$ & $0.5886^{*}$ \\
\hline
\end{tabular}

Chi-square test for independence or Fisher's exact probability, *Mann-Whitney's $U$ test

strong independent predictor of HFNEF with less elevated BNP.

\section{Discussion}

The present findings suggest a relationship between HFNEF with less elevated BNP and history of OHS. Fur- thermore, in the B group, patients who had a history of OHS had a significantly lower BNP level. HFNEF with less elevated BNP was associated with a lower rate of history of hypertension as well as low values for left ventricular hypertrophy parameters. Patients in the NB group who had a history of OHS had marked left atrial enlargement, 


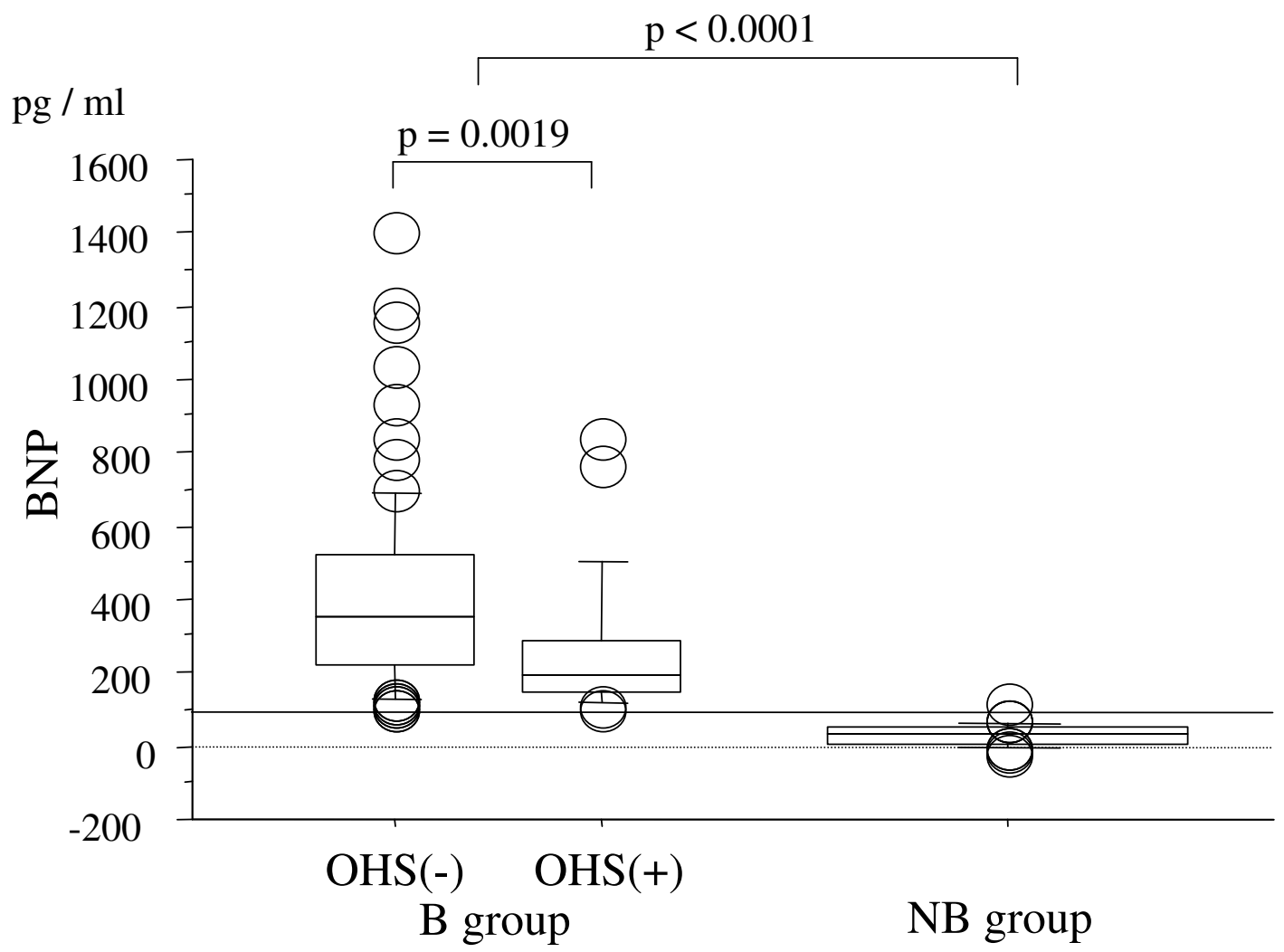

Figure I

Comparison of level of B-type natriuretic peptide (BNP) in B group between with and without a history of open-heart surgery (OHS). Patients who had a history of OHS had a significantly lower BNP level. The boxes represent the 25 th, 50 th(median), and 75 th percentiles, and the whiskers indicate the 10 th and 90 th percentiles.

Table 2: Echocardiographic findings

\begin{tabular}{|c|c|c|c|}
\hline & B group & NB group & $P$ \\
\hline LAd (median) (mm) & $47.5 \pm 8.6(46)$ & $56.5 \pm 17.2(53)$ & 0.0026 \\
\hline IVST (median) (mm) & $11.8 \pm 2.9(\mathrm{II})$ & $10.0 \pm 2.7(10)$ & 0.0005 \\
\hline PWT (median) (mm) & $11.3 \pm 2.5(11)$ & $10.4 \pm 2.6(10)$ & 0.0225 \\
\hline LVDd (median) (mm) & $47.1 \pm 5.9(49)$ & $47.3 \pm 6.3(46)$ & 0.4797 \\
\hline LVDs (median) (mm) & $30.5 \pm 5.2(31)$ & $29.6 \pm 5.4(30)$ & 0.1566 \\
\hline EF (median) $(\%)$ & $65.7 \pm 8.5(66)$ & $67.1 \pm 6.8(67.5)$ & 0.3042 \\
\hline RWT (median) & $0.49 \pm 0.13(0.48)$ & $0.44 \pm 0.13(0.42)$ & 0.0114 \\
\hline LVMI (median) $\left(\mathrm{g} / \mathrm{m}^{2.7}\right)$ & $73.1 \pm 26.1$ (70.1) & $60.7 \pm 24.8(55.1)$ & 0.0051 \\
\hline $\mathrm{E} / \mathrm{A}$ (median) & $1.3 \pm 0.6(1.2)$ & $1.2 \pm 0.5(1.1)$ & 0.7499 \\
\hline Dct (median) (ms) & $213.3 \pm 80.4(185)$ & $235.0 \pm 79.4(230)$ & 0.3367 \\
\hline RVSP (median) (mmHg) & $48.2 \pm 14.6(45)$ & $44.7 \pm 12.5(41.5)$ & 0.3035 \\
\hline TR (\%) & $24(25)$ & $15(33)$ & $0.2907^{*}$ \\
\hline
\end{tabular}

Mann-Whitney's $U$ test, $*$ Chi-square test for independence or Fisher's exact probability

LAd: left atrial diameters, IVST; interventricular septal thickness, PWT; posterior wall thickness, LVDd: left ventricular end-diastolic diameters,

LVDs: left ventricular end-systolic diameters, EF: ejection fraction, LVMI: left ventricular mass index, RWT: relative wall thickness, E/A: peak early filling velocity to atrial filling velocity ratio, Dct: deceleration time of peak early filling velocity, RVSP: right ventricular systolic pressure, TR: tricuspid regurgitation 


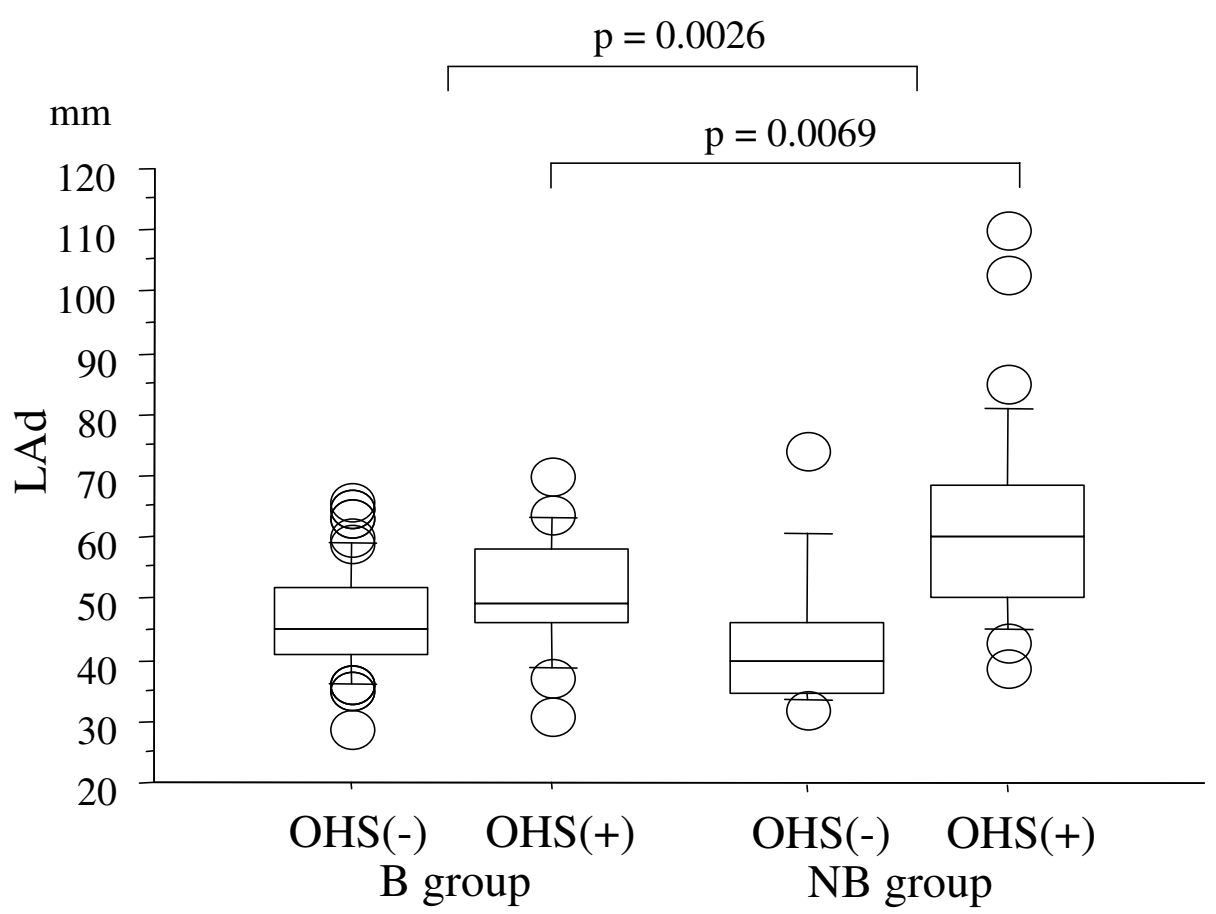

Figure 2

Comparison of left atrial diameters (LAd) between B group and NB group. Patients in the NB group who had a history of open-heart surgery had marked left atrial enlargement. The boxes represent the 25th, 50th (median), and 75th percentiles, and the whiskers indicate the 10 th and 90 th percentiles.

which may indicate permanent atrial fibrillation and pericardial constriction. Pericardial involvement may be responsible for HFNEF with less elevated BNP.

\section{Predominant mechanism of BNP release}

Brain natriuretic peptide is secreted from the ventricles in response to increased ventricular wall stress in addition to myocardial stretch. Because a clear correlation is generally observed between left ventricular end-diastolic pressure (LVEDP) and BNP levels, BNP is used in the differential diagnosis of heart failure [17]. Merisel et al. recommend a cutoff value of $100 \mathrm{pg} / \mathrm{ml}$ of BNP in the diagnosis of heart failure [5].

However, in constrictive pericarditis, BNP does not increase despite increases in LVEDP [18]. Therefore, BNP

Table 3: Multiple logistic regression analysis of factors used for differentiating between patients with elevated BNP and those with less elevated BNP

\begin{tabular}{llll}
\hline Analysis & Predictor & Odds Ratio $(95 \% \mathrm{Cl})$ & $\mathrm{P}$ \\
\hline Univariate & History of open-heart surgery & $8.91(3.98-19.9)$ & $<0.0001$ \\
& IVST & $0.77(0.66-0.91)$ & 0.0018 \\
& LAd & $1.06(1.03-1.10)$ & 0.0005 \\
History of hypertension & $0.27(0.12-0.58)$ & 0.0008 \\
Multivariate & PAC & $1.16(1.05-1.18)$ & 0.0002 \\
& History of open-heart surgery & $3.60(1.17-11.03)$ & 0.0252 \\
& IVST & $0.99(0.80-1.21)$ & 0.8838 \\
& LAd & $1.02(0.98-1.07)$ & 0.3743 \\
& History of hypertension & $0.36(0.12-1.08)$ & 0.0683 \\
& PAC & $1.06(0.99-1.13)$ & 0.1059 \\
\hline
\end{tabular}

The odds ratio reflects the odds for patients with the characteristic in question as compared with those without the characteristic. $\mathrm{Cl}$ denotes confidence interval

LAd; left atrial diameters, IVST; interventricular septal thickness, PAC; plasma aldosterone 
has been reported to be a useful marker for differentiating constrictive pericarditis from restrictive cardiomyopathy [10]. During pericardial constriction with no distensibility, which is caused by factors such as constrictive pericarditis, no increases in transmural pressure are observed despite increases in intracavity pressure or left ventricular filling pressure, and myocardial stretch is inhibited [11]. Natriuretic peptide is clinically known to increase following pericardiectomy as well as removal of pericardial fluid [18-21]. Pericardiectomy or pericardiocentesis causes significant reductions in intrapericardial pressures, significant increases in transmural pressures and wall tension, and myocardial stretch $[19,21]$. Thus, natriuretic peptide secretion is thought to be stimulated by myocardial stretch resulting from increased transmural pressure, rather than by increased intracavity pressure [20].

\section{Pericardial adhesion in patients with prior open-heart surgery}

In developed countries, the most frequent causes of constrictive pericarditis are prior cardiac surgery, idiopathic pericarditis, and irradiation therapy [22]. Pericardial adhesion, which is commonly observed following OHS, constitutes a problem during repeat surgery and may be an extracardiac factor that contributes to heart failure $[22,23]$. Because the postoperative patients have a long postoperative period following pericardiotomy, pericardial stretch is thought to be limited. In these patients, heart failure may easily become evident due to factors such as increased heart rate, salt or water loading, renal dysfunction and infection. The diagnosis of constrictive pericarditis should be considered in patients presenting with unexplained right sided heart failure and normal ejection fraction after cardiac surgery [24].

\section{Atrial degeneration and BNP secretion}

B-type natriuretic peptide is also expressed and secreted in atrial tissue, and is stored in atrial granules along with ANP $[25,26]$. BNP also increases in $\mathrm{AF}$ and has been reported to exceed $100 \mathrm{pg} / \mathrm{ml}$ [27]. Therefore, the use of BNP in the differential diagnosis of breathlessness caused by AF may result in overdiagnosis of heart failure [28]. The kinetics of atrial-derived BNP in heart failure has not yet been elucidated. Although ANP increases in AF, it has been reported to decrease over time, possibly due to degeneration of atrial muscle $[29,30]$. ANP and BNP are structurally similar and are both stored in secretory granules [31]. In patients with permanent $\mathrm{AF}$ and enlarged atrial size, BNP is thought to decrease in a similar manner to ANP due to degeneration of atrial tissue. In HFNEF with a long postoperative period following OHS, especially valve replacement, the net increase in BNP is thought to be small due to more permanent $\mathrm{AF}$ resulting in severe atrial damage.

\section{Study Limitations and Perspectives}

In the present study, evidence for pericardial lesions was based only on history of OHS and tendency toward pericardial thickening. Although radiographic determination of pericardium thickness is often taken into account during the assessment of constrictive pericarditis, increased pericardial thickness dose not necessarily imply constriction. Conversely, constrictive pericarditis can occur in patients with normal pericardium thickness [23]. It should not be denied because of normal pericardial thickness demonstrated by radiographic imaging when clinical, echocardiographic, or invasive hemodynamic features indicate constriction [23].

Hemodynamic assessment using right heart catheterization was performed for only two patients. However, noncompliant patterns, which are regarded as characteristic findings in constrictive pericarditis, were also observed in restrictive cardiomyopathies such as right ventricular infarction and amyloidosis, and were thus not a definitive finding. Furthermore, no characteristic waveforms are thought to be associated with mild constrictive pericarditis and effusive pericarditis. For the definitive diagnosis of constrictive pericarditis, it is essential to clarify the presence of intracardiac and intrathoracic dissociation and the presence of ventricular discordance. Therefore, constrictive pericarditis is often difficult to diagnose requiring careful attention to detail during measurement of hemodynamics. Eventually, the diagnosis of constrictive pericarditis is often confirmed at surgery. Thus, a simple measurement of BNP may be useful for differentiating constriction from restriction in HFNEF. Further study is required to determine the involvement of pericardial lesions in HFNEF with less elevated BNP.

\section{Conclusion}

Acute heart failure with less elevated BNP is associated with a history of open-heart surgery and marked atrial enlargement. No association is observed between the level of BNP and left ventricular function. Atrial degeneration and an extramyocardial factor, particularly pericardium, need to be taken into account in the interpretation of the pathophysiology of heart failure with less elevated BNP. In a patient suspected of HFNEF, a history of open-heart surgery (especially mitral prosthesis) is considered diagnostic evidence of presence of diastolic heart failure when plasma levels of BNP are less elevated.

\section{Competing interests}

The authors declare that they have no competing interests.

\section{Authors' contributions}

KS conceived and designed this study, carried out the data analysis and statistical analysis and drafted the manuscript. NK, KM, MH, YK, AS, and EF performed the collec- 
tion and analysis of data. MK helped to draft the manuscript and added important intellectual content.

\section{All authors read and approved the final manuscript.}

\section{Acknowledgements}

The authors are indebted to the staff of the Tokyo Women's Medical University Aoyama Hospital.

\section{References}

I. Davis M, Espiner E, Richards G, Billings J, Town I, Neill A, Drennan C, Richards M, Turner J, Yandle T: Plasma brain natriuretic peptide in assessment of acute dyspnoea. Lancet 1994, 343:440-444.

2. Lee SC, Stevens TL, Sandberg SM, Heublein DM, Nelson SM, Jougasaki M, Redfield MM, Burnett JC Jr: The potential of brain natriuretic peptide as a biomarker for New York Heart Association class during the outpatient treatment of heart failure. J Card Fail 2002, 8: 149-154.

3. Yoshimura M, Mizuno $Y$, Nakayama M, Sakamoto T, Sugiyama $S$, Kawano H, Soejima H, Hirai N, Saito Y, Nakao K, Yasue H, Ogawa H: B-type natriuretic peptide as a marker of the effects of enalapril in patients with heart failure. Am J Med 2002, I I 2:7 I 6-720.

4. Maisel AS: B-type natriuretic peptide in the diagnosis and management of congestive heart failure. Cardiol Clin 200I, 19:557-57|.

5. Maisel AS, Krishnaswamy P, Nowak RM, McCord J, Hollander JE, Duc P, Omland T, Storrow AB, Abraham WT, Wu AH, Clopton P, Steg PG, Westheim A, Knudsen CW, Perez A, Kazanegra R, Herrmann HC, McCullough PA, Breathing Not Properly Multinational Study Investigators: Rapid measurement of B-type natriuretic peptide in the emergency diagnosis of heart failure. $N$ Engl J Med 2002, I 8(347): $161-167$.

6. Strunk A, Bhalla V, Clopton P, Nowak RM, McCord J, Hollander JE, Duc P, Storrow AB, Abraham WT, Wu AH, Steg G, Perez A, Kazanegra R, Herrmann HC, Aumont MC, McCullough PA, Maisel A: Impact of the history of congestive heart failure on the utility of B-type natriuretic peptide in the emergency diagnosis of heart failure: results from the Breathing Not Properly Multinational Study. Am J Med 2006, I I9:e I-II.

7. Logeart D, Saudubray C, Beyne P, Thabut G, Ennezat PV, Chavelas C, Zanker C, Bouvier E, Solal AC: Comparative value of Doppler echocardiography and B-type natriuretic peptide assay in the etiologic diagnosis of acute dyspnea. J Am Coll Cardiol 2002, 40:1794- 1800

8. Dahlström U: Can natriuretic peptides be used for the diagnosis of diastolic heart failure? Eur J Heart Fail 2004, 6:28I-287.

9. de Lemos JA, McGuire DK, Drazner MH: B-type natriuretic peptide in cardiovascular disease. Lancet 2003, 362:316-322.

10. Leya FS, Arab D, Joyal D, Shioura KM, Lewis BE, Steen LH, Cho L: The efficacy of brain natriuretic peptide levels in differentiating constrictive pericarditis from restrictive cardiomyopathy. J Am Coll Cardiol 2005, 45: 1900-1 902.

II. Spodick DH: Low atrial natriuretic factor levels and absent pulmonary edema in pericardial compression of the heart. Am J Cardiol 1989, 63: I27I-I 272.

12. Kitzman DW, Little WC, Brubaker PH, Anderson RT, Hundley WG, Marburger CT, Brosnihan B, Morgan TM, Stewart KP: Pathophysiological Characterization of Isolated Diastolic Heart Failure in Comparison to Systolic Heart Failure. JAMA 2002, 288:2|44-2। 50 .

13. Hogg K, McMurray J: Neurohumoral pathways in heart failure with preserved systolic function. Prog Cardiovasc Dis 2005, 47:357-366.

14. McKee PA, Castelli WP, McNamara PM, Kannel WB: The natural history of congestive heart failure: The Framingham Study. $N$ Engl J Med I97I, 285: | 44|-| 446.

15. de Simone G, Daniels SR, Devereux RB, Meyer RA, Roman MJ, de Divitiis $\mathrm{O}$, Alderman $\mathrm{MH}$ : Left ventricular mass and body size in normotensive children and adults: assessment of allometric relations and impact of overweight. J Am Coll Cardiol 1992, 20: $125 \mid-1260$

16. de Simone G, Daniels SR, Kimball TR, Roman MJ, Romano C, Chinali $M$, Galderisi M, Devereux RB: Evaluation of concentric left ven- tricular geometry in humans: evidence for age-related systematic underestimation. Hypertension 2005, 45:64-68.

17. Maeda K, Tsutamoto T, Wada A, Hisanaga T, Kinoshita M: Plasma brain natriuretic peptide as a biochemical marker of high left ventricular end-diastolic pressure in patients with symptomatic left ventricular dysfunction. Am Heart J 1998, I35:825-832.

18. Brown T, Hollman J: B-type natriuretic peptide level in a patient with constrictive pericarditis. Catheterization and Cardiovascular Interventions 2006, 68:832-834.

19. Wolozin MW, Ortola FV, Spodick DH, Seifter JL: Release of atrial natriuretic factor after pericardiectomy for chronic constrictive pericarditis. Am J Cardiol 1988, 62: / 323-1325.

20. Spodick $\mathrm{DH}$ : Cardiogenic pulmonary edema and its absence in cardiac tamponade and constriction. A role for atrial natriuretic factor? Chest 1992, I01:258-260.

21. Panayiotou H, Haitas B, Hollister AS: Atrial wall tension changes and the release of atrial natriuretic factor on relief of cardiac tamponade. Am Heart J 1995, I 29:960-967.

22. Bertog SC, Thambidorai SK, Parakh K, Schoenhagen P, Ozduran V, Houghtaling PL, Lytle BW, Blackstone EH, Lauer MS, Klein AL: Constrictive pericarditis: etiology and cause-specific survival after pericardiectomy. J Am Coll Cardiol 2004, 2 I (43): I 445- I 452.

23. Talreja DR, Edwards WD, Danielson GK, Schaff HV, Tajik AJ, Tazelaar HD, Breen JF, Oh JK: Constrictive pericarditis in 26 patients with histologically normal pericardial thickness. Circulation 2003, 108: 1852-1857.

24. Ribeiro P, Sapsford R, Evans T, Parcharidis G, Oakley C: Constrictive pericarditis as a complication of coronary artery bypass surgery. Br Heart J 1984, 5 I:205-210.

25. Doyama K, Fukumoto M, Takemura G, Tanaka M, Oda T, Hasegawa K, Inada T, Ohtani S, Fujiwara T, Itoh H, Nakao K, Sasayama S, Fujiwara $\mathrm{H}$ : Expression and distribution of brain natriuretic peptide in human right atria. J Am Coll Cardiol 1998, 32: |832-I838.

26. Inoue $\mathrm{S}$, Murakami $\mathrm{Y}$, Sano $\mathrm{K}$, Katoh $\mathrm{H}$, Shimada $\mathrm{T}$ : trium as a source of brain natriuretic polypeptide in patients with atrial fibrillation. J Card Failure 2000, 6:92-96.

27. Silvet $H$, Young- $X u$ Y, Walleigh $D$, Ravid $S$ : Brain natriuretic peptide is elevated in outpatients with atrial fibrillation. Am J Cardiol 2003, 92: I | 24- I I27.

28. Knudsen CW, Omland T, Clopton P, Westheim A, Wu AH, Duc P, McCord J, Nowak RM, Hollander JE, Storrow AB, Abraham WT, McCullough PA, Maisel A: Impact of atrial fibrillation on the diagnostic performance of B-type natriuretic peptide concentration in dyspneic patients: an analysis from the breathing not properly multinational study. J Am Coll Cardiol 2005, 46:838-844.

29. Berg MP Van Den, Crijns HJ, Van Veldhuisen DJ, Van Gelder IC, De Kam PJ, Lie KI: Atrial natriuretic peptide in patients with heart failure and chronic atrial fibrillation: role of duration of atrial fibrillation. Am Heart J 1998, I35:242-244.

30. Seino Y, Shimai S, Ibuki C, Itoh K, Takano T, Hayakawa H: Disturbed secretion of atrial natriuretic peptide in patients with persistent atrial standstill. J Am Coll Cardiol 1991, 18:459-463.

31. Hasegawa K, Fujiwara H, Itoh H, Nakao K, Fujiwara T, Imura H, Kawai $\mathrm{C}$ : Light and electron microscopic localization of brain natriuretic peptide in relation to atrial natriuretic peptide in porcine atrium. Circulation 1991, 84:1203-1209.

\section{Pre-publication history}

The pre-publication history for this paper can be accessed here:

http://www.biomedcentral.com/1471-2261/9/2/prepub 